\title{
PENGGUNAAN APLIKASI GEOGEBRA UNTUK MENINGKATKAN MOTIVASI PELAJARAN MATEMATIKA
}

\author{
Erlinawati \\ SMP Negeri 25 Pekanbaru \\ Email : erlina.hontong25@gmail.com
}

\begin{abstract}
Abstrak. Perkembangan teknologi informasi saat ini menjadi pusat perhatian di berbagai bidang, yang salah satunya adalah bidang pendidikan. Teknologi informasi di bidang pendidikan memiliki peran penting dalam proses pembelajaran, yaitu mentransfer ilmu. Program komputer dapat mensimulasikan pembelajaran terhadap kondisi aktual dari materi yang abstrak. Matematika adalah studi ilmu material yang memiliki objek abstrak. Selain itu, matematika juga merupakan ilmu universal yang mendasari perkembangan teknologi modern. Berbagai teknologi dapat dimanfaatkan sebagai media pembelajaran matematika Salah satu media pembelajaran yang menunjang pengiriman materi matematika adalah aplikasi Geogebra. Geogebra adalah program yang dinamis dengan berbagai fasilitas yang dapat digunakan sebagai media pembelajaran matematika untuk menunjukkan atau memvisualisasikan konsep matematika serta alat untuk membangun konsep matematika. Geogebra memiliki tampilan yang sederhana, penggunaan perangkat lunak interaktif dapat menjadikan perangkat lunak Geogebra menjadi pilihan yang tepat dalam menyampaikan konsep-konsep matematika. Geogebra juga menampilkan animasi yang menarik sehingga peserta didik termotivasi untuk belajar matematika. Makalah ini akan menyajikan deskripsi aplikasi Geogebra dan contoh aplikasi Geogebra sebagai media pembelajaran matematika. Makalah ini menyajikan deskripsi program Geogebra dan contoh penerapan Geogebra sebagai media pembelajaran matematika.
\end{abstract}

Kata Kunci: Geogebra, Media, Motivasi, Hasil belajar

\section{PENDAHULUAN}

Perkembangan teknologi semakin pesat dan cenderung ke arah digitalisasi akibatnya teknologi dapat dimanfaatkan untuk meningkatkan kualitas pembelajaran. Pemanfaatan teknologi dalam proses pembelajaran terutama teknologi komputer memudahkan para guru untuk menyampaikan materi pelajaran yang bersifat abstrak dan logis. Adanya komputer dalam pelajaran matematika akan memudahkan peserta didik untuk memahami materi yang dipelajari.

Teknologi komputer membantu para guru untuk melakukan simulasi pembelajaran ke arah kondisi yang sebenarnya dari materi yang bersifat abstrak. Saat ini banyak berkembang berbagai teknologi yang dapat dimanfaatkan untuk mengembangkan dunia pendidikan. Dalam pelajaran matematika digunakan sebagai media pembelajaran. Salah satu media pembelajaran yang menunjang penyampaian materi matematika adalah aplikasi Geogebra.

Geogebra mempunyai tampilan sederhana, penggunaan software yang interaktif dapat menjadikan software Geogebra menjadi pilihan yang tepat dalam menyampaikan konsep-konsep matematika. Geogebra sebagai media pembelajaran menampilkan informasi materi dalam bentuk demonstrasi atau memvisualisasikan konsep-konsep matematika serta menjadi alat bantu untuk mengkonstruksikan konsep-konsep tersebut. Geogebra juga menampilkan animasi-animasi yang menarik sehingga peserta didik termotivasi untuk belajar matematika. Makalah ini akan menyajikan uraian mengenai aplikasi Geogebra beserta contoh-contoh penerapan Geogebra sebagai media pembelajaran matematika.

Berdasarkan hal tersebut, maka peneliti tertarik untuk melakukan penelitian dengan judul "Penggunaan Aplikasi Geogebra untuk meningkatkan motivasi pelajaran matematika".

\section{METODE}

Jenis penelitian yang akan dilakukan adalah Penelitian Tindakan Kelas. Menurut Kunandar (2008:41) PTK memiliki peranan yang sangat penting dan strategis untuk meningkatkan mutu pembelajaran apabila diimplementasikan dengan baik dan benar.

Penelitian ini merupakan penelitian tindakan kelas (PTK) dengan subjek penelitian siswa kelas IX SMP Negeri 25 Pekanbaru Tahun Ajaran 2018/2019. Penelitian ini adalah berupa pemberian tindakan pembelajaran matematika berbantuan media pembelajaran 
berbasis Geogebra, sedangkan untuk pemahaman konsep siswa, dicerminkan dengan skor tes yang mereka peroleh dan motivasi belajar mereka sebagai akibat dari pemberian tindakan. Tingkat pemahaman siswa terhadap konsep-konsep matematika (bangun datar dan bangun ruang) diukur dengan menggunakan tes hasil belajar bebentuk uraian, sedangkan motivasi diukur dengan menggunakan kuesioner dengan 3 kategori (skala Likert). Selanjutnya skor tes yang diperoleh siswa dianalisis dengan menggunakan statistic deskriptif. Meningkatnya pemahaman siswa terhadap konsep-konsep matematika sebagai akibat dari pemberian tindakan dideteksi dari dari adanya peningkatan rata-rata skor tes dari siklus ke siklus. Untuk mengetahui motivasi belajar siswa sebagai akibat dari pemberian tindakan dideteksi melalui tingkat motivasi siswa yang diperoleh dari analisis data kuesioner. Data kuesioner ini diklasifikasikan ke dalam 3 tingkatan; tinggi, sedang, rendah.

\section{HASIL DAN PEMBAHASAN}

Menurut (Hamalik dalam Azhar, 2009:2), media merupakan alat komunikasi yang dapat mengefektifkan proses belajar mengajar. Media tidak terpisahkan dari pembelajaran demi tercapainya tujuan pendidikan pada umumnya dan tujuan pembelajaran pada khususnya. Disamping sebagai sistem penyampai atau pengantar, media menunjukkan fungsi atau perannya, yaitu mengatur hubungan yang efektif antara dua pihak utama dalam proses belajar.

Sadiman dkk (2009:7) menyatakan media dalam pembelajaran berfungsi memperjelas penyajian pesan agar tidak terlalu bersifat verbalisme. Penggunaan media yang tepat dan bervariasi dapat mengatasi sikap pasif peserta didik, sehingga dapat menimbulkan gairah belajar, dan memungkinkan interaksi yang lebih langsung antara peserta didik dengan lingkungan serta kenyataan.

Arifin \& Setiyawan (2012:17) menjelaskan penggunaan media dalam pelajaran matematika memberikan kesempatan kepada peserta didik untuk merekonstruksi pengetahuan yang perlu diketahui, lewat berbuat, mengamati, dan mengklasifikasi.Komputer merupakan salah media yang digunakan dalam pelajaran matematika dapat mengemas pembelajaran lebih menarik, menyenangkan, efektif, dan efisien bagi guru dan peserta didik.

Kesimpulannya penggunaan media yang tepat dan berinovasi dapat menjadikan proses pembelajaran matematika lebih menarik dan menimbulkan motivasi serta semangat peserta didik dalam pembelajaran. Hal ini dikarenakan media sebagai penyampai informasi menunjukkan fungsi untuk mengatur hubungan yang efektif antara dua pihak yaitu peserta didik dan materi yang dipelajari. Salah satu media yang dimaksud adalah komputer.

Geogebra merupakan salah satu aplikasi komputer, program-program yang ada bermanfaat pada pelajaran matematika dikemukakan oleh Kusuma (2003). Programprogam komputer sangat tepat untuk menyampaikan konsep-konsep matematika yang memerlukan ketelitian, konsep yang relatif, dan penyelesaian garis. Selanjutnya Kusuma (2003) mengemukakan inovasi pembelajaran dengan menggunakan komputer sangat tepat untuk diintegrasikan dalam pembelajaran konsep matematika.

Beberapa pemanfaatan program Geogebra dalam pembelajaran matematika adalah:

1. Menghasilkan lukisan-lukisan geometri dengan cepat dan teliti.

2. Mempunyai animasi-animasi dan gerakangerakan manipulasi (dragging).

3. Memberikan pengalaman visual yang lebih jelas kepada siswa dalam memahami konsep geometri

4. Dimanfaatkan sebagai evaluasi untuk memastikan bahwa lukisan yang telah dibuat benar.

5. Mempermudah guru dan siswa untuk menyelidiki atau menunjukkan sifat-sifat yang berlaku pada suatu objek geometri. (Lavicza dalam Howenwater, 2010)

Menurut Howenwarter\&Fuchs (2004), Geogebra sangat bermanfaat sebagai media pembelajaran matematika dengan berbagai aktivitas yaitu; sebagai media demonstrasi, visualisasi, alat bantu kontruksi, dan alat bantu penemuan.

Menu utama Geogebra adalah: file, Edit,View, Option, Windows, dan Help untuk menggambar objek-objek geometri. Menu file digunakan untuk membuat, membuka, menyimpan, dan mengeksplor file, serta keluar 
PRINSIP Pendidikan Matematika

Volume 1, Nomor 1, November 2018

program. Menu Edit untuk mengedit lukisan. Menu View digunakan untuk mengatur tampilan. Menu option untuk mengatur berbagai fitur tampilan, seperti pengaturan ukuran huruf, pengaturan jenis (style) objekobjek geometri, dan sebagainya. Berikut ini akan ditampilkan menu dalam Geogebra.

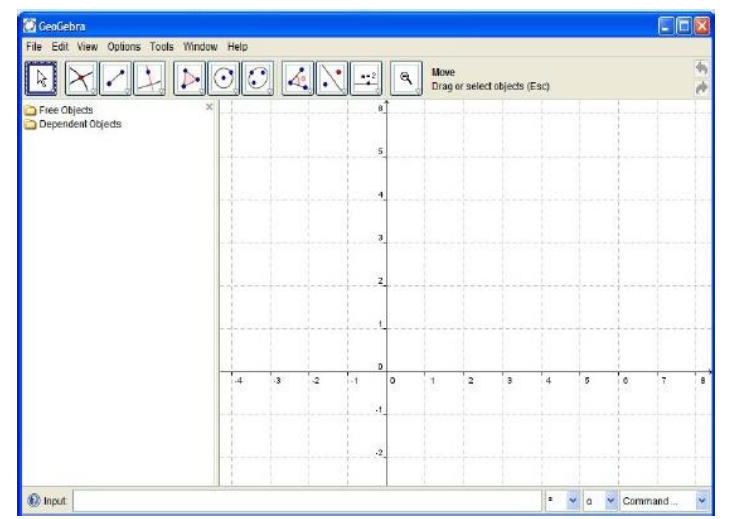

Gambar 1. Menu Geogebra

1. Pembuatan animasi dalam aplikasi Geogebra

Berikut ini akan disajikan beberapa pembuatan animmasi Geogebra yang dapat dimanfaatkan dalam pelajaran matematika.

a. Jaring-jaring kubus

- Geogebra kita buka, tampilan utama seperti gambar 1. Menu Geogebra

- Buat gambar kubus berdasarkan dua titik yang ada, pilih poin misalkan kordinatnya titik $(-2,2)$ dan titik $(-2,-$ 2)

- Ketik di input Cube, kemudian pilih poin (<point $>,<$ point $>)$

- Ketik point pertama A, point kedua $\mathrm{B}$, akan membentuk gambar segi empat persegi,seperti gambar berikut:

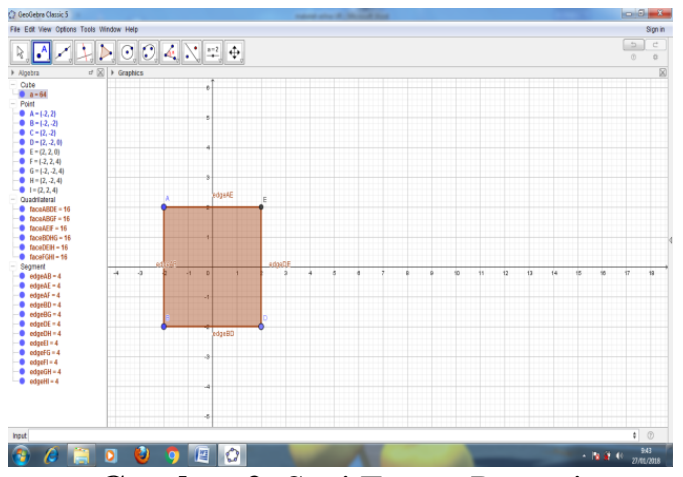

Gambar 2. Segi Empat Persegi
Plih View, klik 3D Grapichs, arahkan cursor ke sebelah kiri gambar segi empat persegi akan menghasilkan gambar 3:

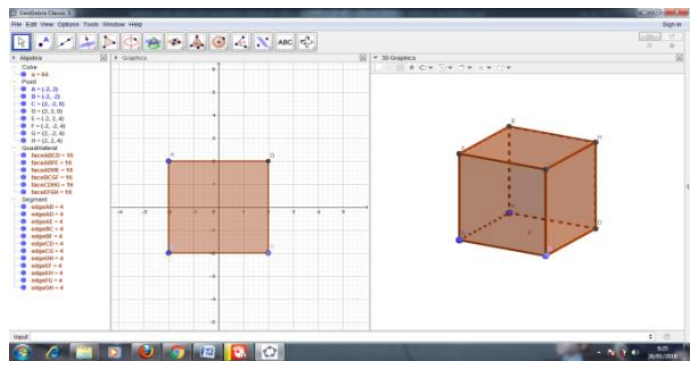

Gambar 3. Kubus

- Supaya tidak terlalu ramai, hilangkan sumbu $\mathrm{x}, \mathrm{y}, \mathrm{z}$, dan alasnya denga cara klik kanan, klik kiri Axes dan Plane, Maka akan tampil gambar.

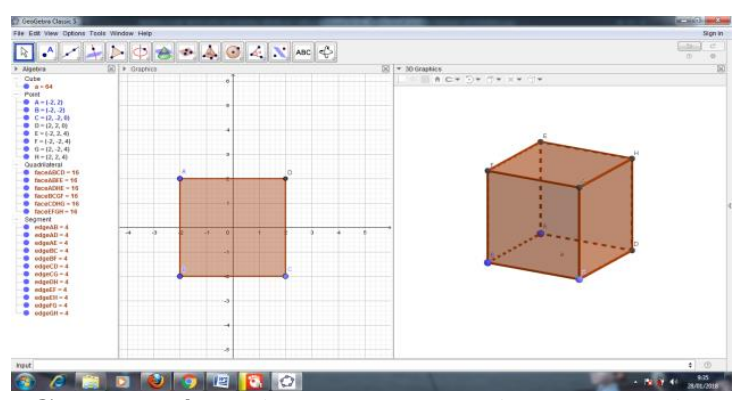

Gambar 4. Kubus Tanpa Sumbu X,Y,Z, dan Bayangan

- Nama rusuk dibuang saja, dengan cara klik di segment tulisan edge $\mathrm{B}=4$ sampai edgeGH=4, kemudian klik kanan, pilih show label, nama-nama rusuk akan hilang

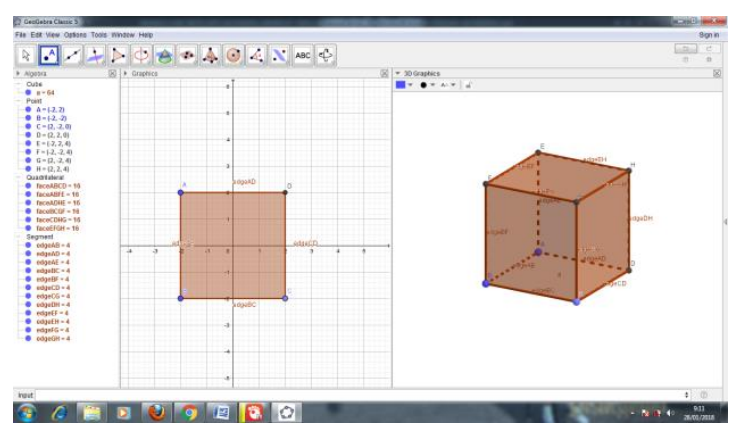

Gambar 5. Nama-Nama Rusuk Hilang

- Kubus di buka untuk membuat jaringjaring, caranya pilih pyramid, klik Net, arahkan cursor ke gambar kubus, kemudian klik. Hasil tampilan adalah: 
PRINSIP Pendidikan Matematika

Volume 1, Nomor 1, November 2018

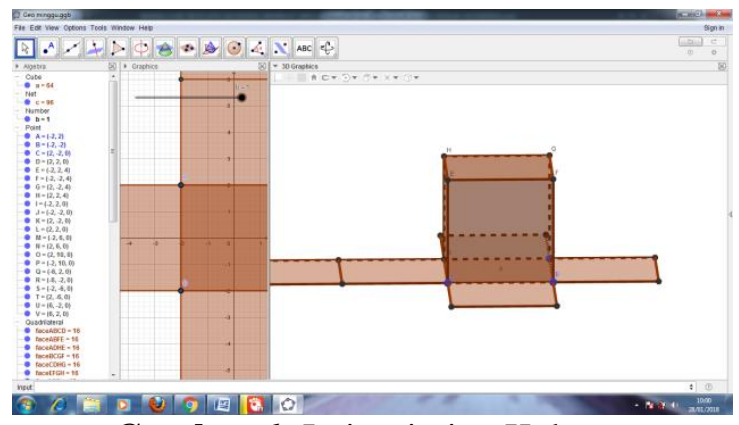

Gambar 6. Jaring-jaring Kubus

- Gambar kubus dibuang, pilih Quadrilateral, klik bulatan sebelah face ABCD sampai faceEFGH, gambar sisi kubus akan hilang

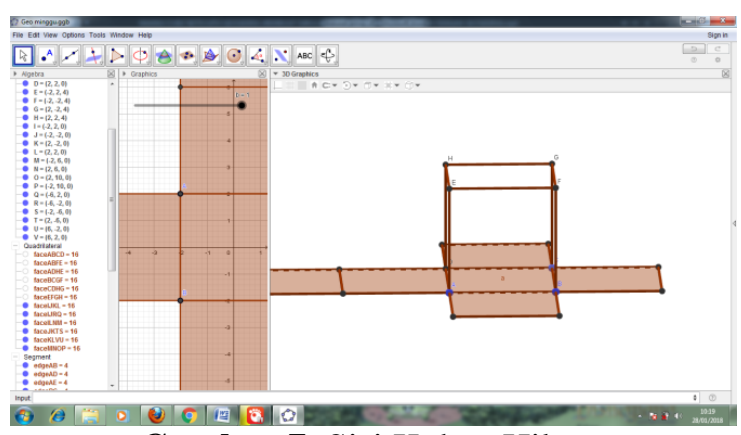

Gambar 7. Sisi Kubus Hilang

Hilangkan rusuk-rusuk kubus, pilih segment, klik bulatan edegAB sampai edegGH kemudian perhatikan tulisan dibawah Cube yaitu a $=64$ diklik, selanjutnya Point, klik bulatan A sampai $\mathrm{H}$, hasilnya.

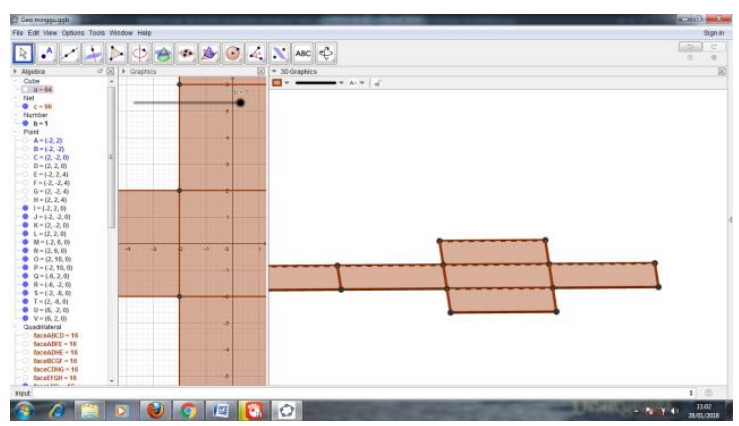

Gambar 8. Rusuk-rusuk Kubus Hilang

- Warna jaring-jaring kubus bisa diubah, sesuai keinginan. Caranya klik sisi kubus satu persatu pilih warna di bawah tulisan 3D Graphics. Gambar akan tampil

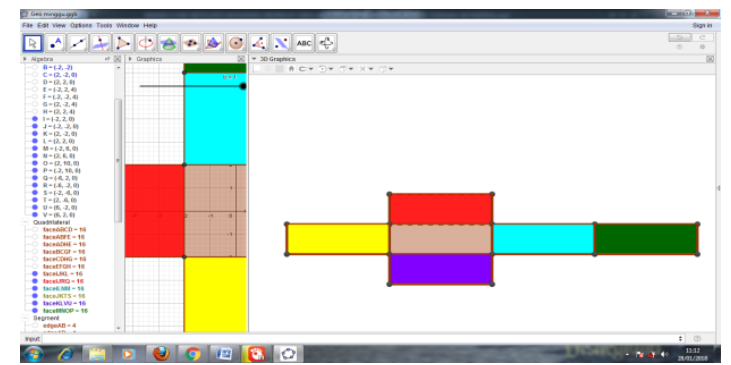

Gambar 9. Warna Kubus

- Untuk mengatur garis, blok adgeAb sampai adgeUV dibawah segment, klik kanan, pilih object Properties, color, style, atur Line Thicknees, line opacity, tutup. Cara tersebut bisa untuk memperbesar dan memperkecil garis.

- Untuk menggerakkan gambar klik kanan garis hitam $\mathrm{b}=1$, pilih Animation On, jari-jaring kubus akan bergerak buka tutup.

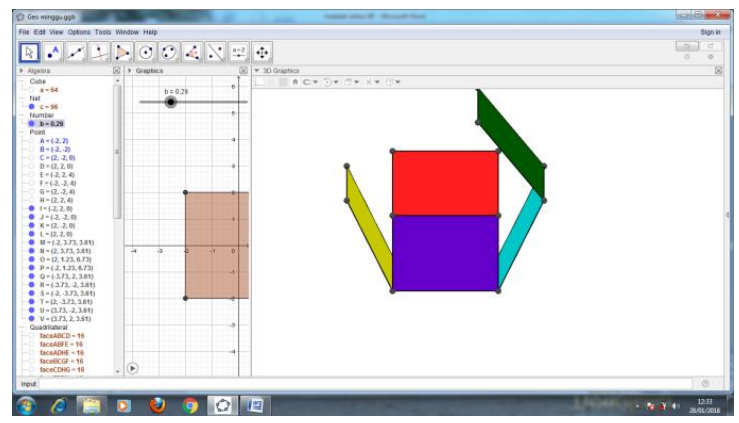

Gambar 10. Kubus Buka Tutup

b. Jaring-jaring limas segi n beraturan

Buka tampilan Geogebra seperti pada gambar 1, kemudian pilih View, klik 3D Graphics akan tampil gambar

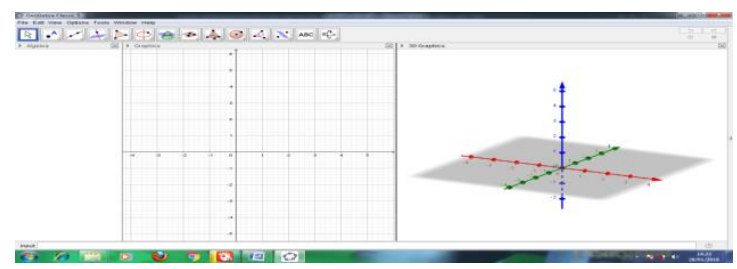

Gambar 11. Tempat Alas Limas Segi-n Beraturan

Untuk membuat limas, buat dulu alasnya pilih Regular Polygon, tentukan panjang rusuknya, misalkan dua, karena segi lima tulis 5, ok akan muncul gambar 
PRINSIP Pendidikan Matematika

Volume 1, Nomor 1, November 2018

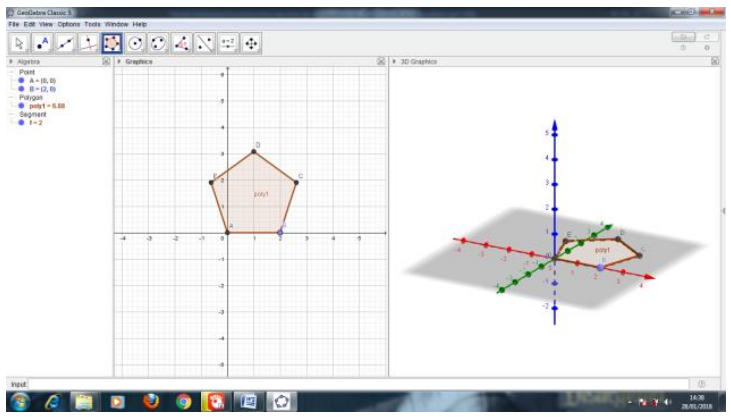

Gambar 12. Alas Limas Segi Lima Beraturan

- Membuat tinggi limas arahkan cursor ke tampilan 3D Graphics, pilih Extrude to pyramid or con, kemudian tentukan tinggi limas, misalkan 3, ok. Muncul gambar

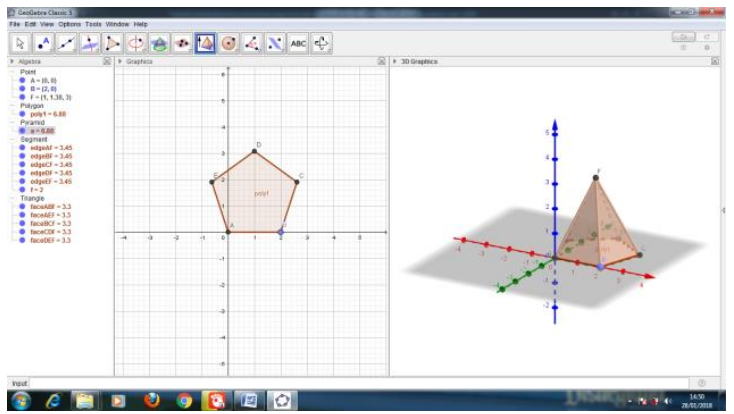

Gambar 13. Limas Segi Lima Beraturan

- Membuat jaring-jaring limas, pilih Net, arahkan cursor ke gambar limas, tampilan berubah menjadi

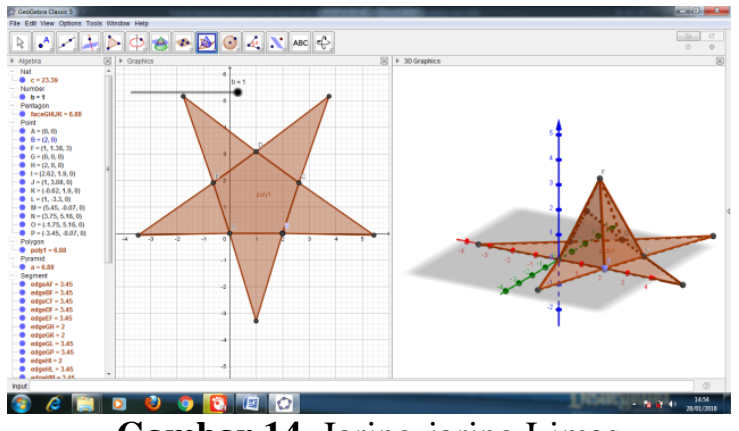

Gambar 14. Jaring-jaring Limas

- Untuk menghilangkan nama-nama rusuk, blok tulisan di bawah segment edge 1 sampai edegEF, klik kanan, pilih show objec.

- Mengganti warna sama caranya pada jaringjaring kubus

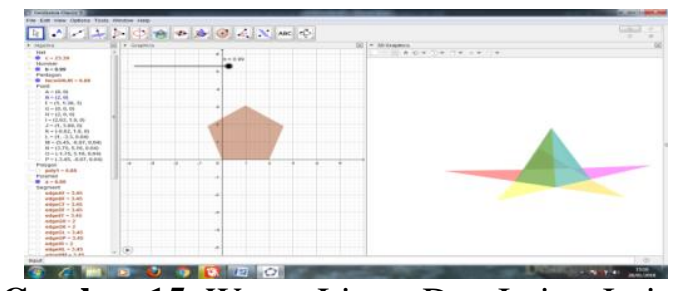

Gambar 15. Warna Limas Dan Jaring-Jaring Berubah

- Klik kanan garis yang bewarna hitam, pilih Animation On, gambar akan bergerak

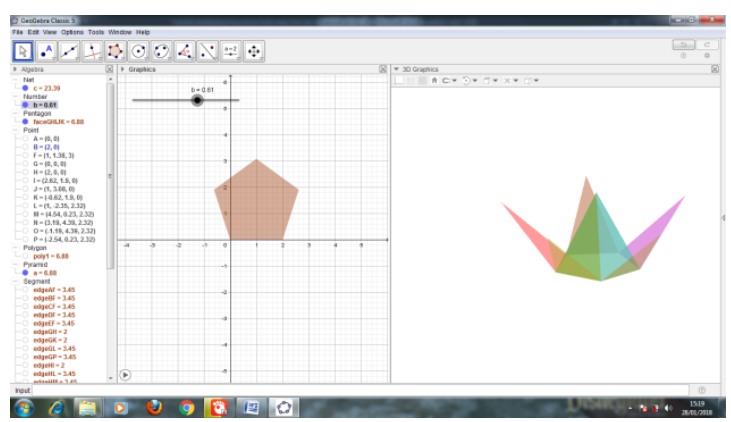

Gambar 16. Jaring-jaring Limas Bergerak

c. Bangun Ruang Bola ada dua cara

- Buka tampilan Geogebra, pilih View 3D Graphichs,

- Untuk cara pertama menggunakan Sphere with center through point tampilan gambar

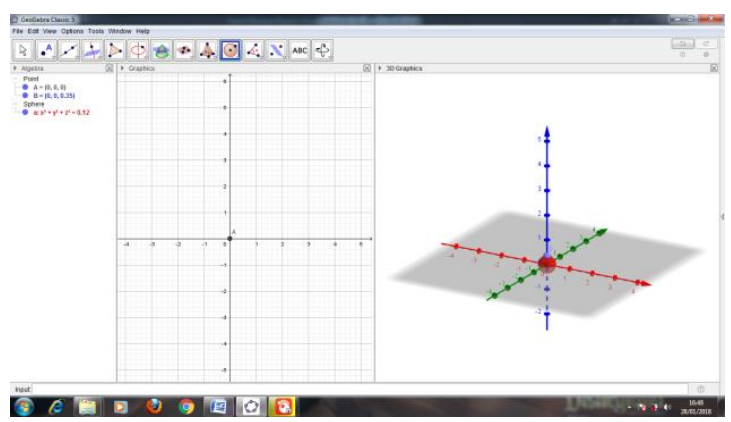

Gambar 17. Bola dengan Cara Sphere With

Center Through Point

- Supaya berbentuk bola tarik sesuai dengan keinginan

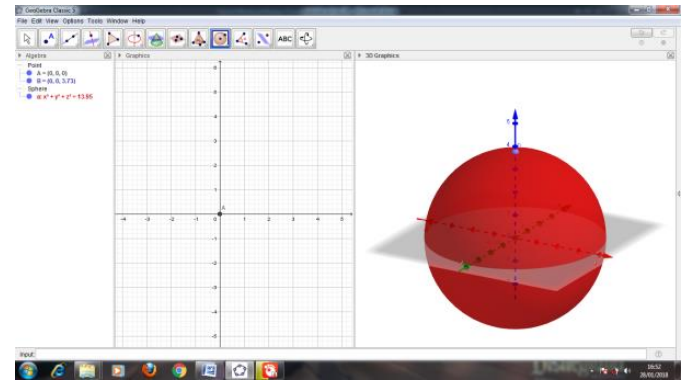

Gambar 18. Bola 
- Cara ke dua Sphere with center and radius, dasarnya sama dengan cara pertama, pusat boleh diambil dari sumbu mana saja $\mathrm{z}$ misalnya, kita tuliskan jarijari yang kita mau misalkan 2, klik ok. Merubah warna background klik kanan, pilih graphics, Background color, ok.tampilan menjadi

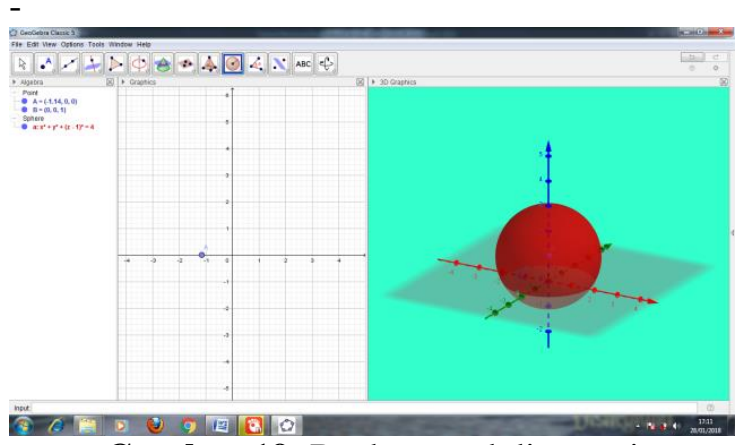

Gambar 19. Background diwarnai

- Warna bola caranya sama dengan jaringjaring kubus dan limas.

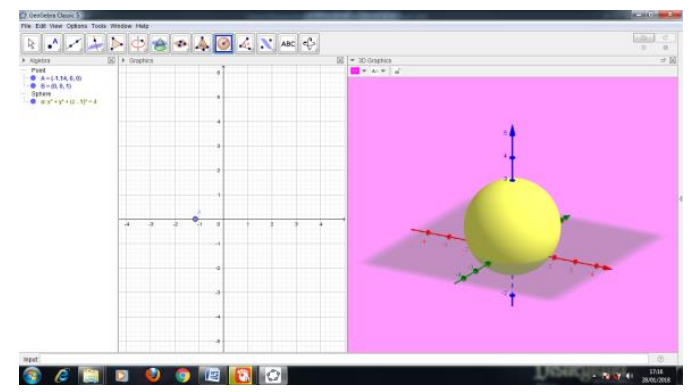

Gambar 20. Mewarnai Bola

\section{SIMPULAN}

Penggunaan komputer dalam dunia pendidikan telah menjadi perhatian utama. Adanya software komputer memberikan manfaat besar dalam proses pembelajaran. Sebagai contoh, Geogebra merupakan salah satu software yang menggabungkan konsep bangun datar dan bangun ruang. Konsep pada materi geometri yang bersifat abstrak dapat dibuat menjadi lebih konkrit dengan bantuan Geogebra. Pada makalah ini dibahas mengenai media pembelajaran Geogebra dalam pembelajaran geometri bidang yaitu limas, kubus, dan bola. Adanya penggunaan Geogebra dalam pembelajaran materi Geometri bidang diharapkan mampu memotivasi siswa untuk lebih tertarik belajar matematika dan lebih mudah memahami materi yang bersifat abstrak.

\section{DAFTAR PUSTAKA}

Arifin, Z \& Setiyawan, A. (2012). Pengembangan Pembelajaran Aktif. Yogyakarta: PT. Skripta Media Creative.

Kunandar. (2008). Penelitian Tindakan Kelas. Jakarta: PT. Raja Grafindo Persada.

Sadiman, A. Rahardjo, Haryono, A. (1986). Media Pendidikan. Jakarta: PT. Raja Grafindo Persada. 